\title{
Simulation Possibilities of 3D Measuring in Progressive Control of Production
}

\author{
Mário Drbúl ${ }^{1}$, Dana Stančeková ${ }^{1}$, Ondrej Babík ${ }^{1}$, Jozef Holubjak ${ }^{1}$, Ingrid Görögová , Daniel Varga $^{1}$ \\ ${ }^{1}$ Katedra obrábania a výrobnej techniky, Strojnícka fakulta, Žilinská univerzita v Žiline Univerzitná1, 01026 Žilina, Slo- \\ venská republika: mario.drbul@fstroj.uniza.sk, dana.stancekova@fstroj.uniza.sk, ondrej.babik@ fstroj.uniza.sk, jo- \\ zef.holubjak@fstroj.uniza.sk \\ ${ }^{2}$ Materiálovotechnologická fakulta STU v Trnave, Ústav výrobných technológií, J. Bottu 23, 91724 Trnava, Slovenská \\ republika: qgorogova@stuba.sk
}

The product price consists from several items. Time needed for adequate control of product is one of the most significant items, which can get expensive. So it is important, how the measurement strategy (measurement plan) is prepared. Time, which is not used for control of products by 3D measurement machine, is financial loss for company. This article deals with simulation of contact measurement, as a progressive tool, for preparation and creation of measurement plans for 3D coordinate measurement machines. Furthermore, the article deals with factors, that are not taken into account by offline programming during creation of measurement plan. Those can ultimately lead to significant difference between measurement simulation and measurement performed in workspace of measurement machines or CNC machines. This difference can cause serious shortcomings in measurement plans created in offline programming modules.

Keywords: Off-line programming, simulation measurement, coordinate measuring machine, CAD model

\section{Acknowledgement}

This work was supported in part by the VEGA č. 1/0836/13.

\section{References}

[1] [online]. 2015, [cit. 2015-02-12]. Available on internet: http://www.solidcam.cz/cam-solutions/solid-probe/onmachine-verification/

[2] [online]. 2015, [cit. 2015-02-12]. Available on internet: http://www.renishaw.cz

[3] POKORNÝ, P.:Souřadnicové měřicí stroje. Skriptá TU v Liberci. Liberec 1999 ISBN 80-7083-326-2

[4] Precision styli, 2015. [online]. 2015, [cit. 2015-02-12]. Available on internet:http://www.renishaw.cz/cs/naspicce-pruvodce-pro-vyber-doteku-pro-souradnicovymerici-stroj--10927

[5] MEŠKO, J. - ZRAK, A. - MULCZYK, K. - TOFIL, S.: Microstructure analysis of welded joints after laser welding, In: Manufacturing Technology: journal for science, research and production, Vol. 14, No. 3 (2014), s. 355359. ISSN 1213-2489, Kód: ADM. 